\title{
DINÂMICA POLÍTICO-ELEITORAL, BUROCRACIA E GASTO SOCIAL ESTADUAL ${ }^{1}$
}

\author{
André Borges*
}

\begin{abstract}
O trabalho analisa os efeitos da descentralização da autoridade e dos recursos fiscais sobre processos e resultados de políticas públicas. Busca mapear as conexões entre política eleitoral, burocracia, formulação e implementação de políticas sociais na esfera dos estados. São enfocadas as políticas de construção e reforma de escolas do governo do estado da Bahia ao longo de duas gestões (1999-2002 e 2003-2006). O artigo se concentra no impacto da política eleitoral e partidária sobre a alocação dos investimentos da Secretaria da Educação entre os municípios do estado, e ainda analisa o papel das nomeações dos cargos de alto escalão da burocracia setorial na construção da política pública. A análise se apoia em uma estratégia multimétodo, que combina modelos estatísticos multivariados e técnicas tradicionais de estudos de caso. PALAVRAS-CHAVE: governo estadual, eleições, gasto social, burocracia.
\end{abstract}

No Brasil pós-democratização, construiu-se um sistema político em que as instituições e interesses subnacionais desempenham papel substancial na dinâmica eleitoral e de formulação de políticas públicas. A Constituição de 1988 introduziu uma variante "robusta" de federalismo, em que os governos locais e, especialmente, os estaduais, ganharam a capacidade de implementar um amplo leque de políticas sociais e econômicas, e ainda garantiram, sob diversas formas, a representação dos interesses subnacionais na arena política nacional (Ames, 1987; Hagopian, 1996; Mainwaring, 1997; Samuels, 2000; 2003). Para a maioria dos analistas políticos, o "novo federalismo" permitiu

* Doutor em Ciência Política. Professor do Instituto de Ciência Política da Universidade de Brasília - UnB. Campus Darcy Ribeiro, Asa Norte. Cep: 70904-970. Brasília-DF andrebc@unb.br

${ }^{1}$ Este trabalho contou com o apoio da FAPESB, na forma de uma bolsa de pós-doutorado concedida no período de novembro 2007 a janeiro de 2009. A pesquisa integrou o projeto "Governo, políticas sociais e ciclo eleitoral nos estados brasileiros: o caso da Bahia", coordenada pela professora Celina Souza e apoiada pelo CNPq no biênio 20072009. As bolsistas de iniciação científica Sara Fadigas e Priscilla Cayres prestaram inestimável apoio nas atividades de levantamento e organização dos dados. Gostaria de reconhecer ainda o trabalho cuidadoso dos pareceristas anônimos do Caderno CRH, cujas observações e críticas foram consideradas na revisão final do artigo. a emergência dos governadores dos estados como atores políticos poderosos, ainda que existam discordâncias sobre o grau em que as elites estaduais seriam capazes de exercer influência direta sobre o processo decisório nacional (Abrucio, 1998; Arretche, 2007; Mainwaring, 1999; Souza, 1997). Controvérsias à parte, há um consenso na literatura de que os governos estaduais constituem estruturas importantes de contestação política e construção institucional na democracia brasileira.

Em que pese o status das instituições estaduais como objeto de estudo na ciência política brasileira, ainda existem poucos trabalhos que busquem entender como se dá a formulação e implementação de políticas sociais no nível estadual, e em que medida o jogo político-partidário condiciona e (ou) sofre impactos dessas políticas. Embora seja corrente, no meio acadêmico, assim como na mídia e nas visões do senso comum, a ideia de que os governadores sustentariam seu poderio eleitoral pela utilização de estratégias clientelistas e fisiológicas de distribuição de cargos e verbas, o fato é que ainda existem poucos trabalhos empíricos que se proponham a enfrentar 
seriamente essa questão. Também não sabemos exatamente como opera, no âmbito estadual, uma instituição de suma importância para a implementação de políticas governamentais: a burocracia pública. Se for verdade, como argumenta Abrucio (1998), que o Executivo e suas burocracias se constituem no "centro de gravidade" dos sistemas políticos estaduais, torna-se fundamental compreender os vínculos entre os partidos políticos, o processo eleitoral e a burocracia, especialmente no que diz respeito às estratégias de nomeação de cargos do alto escalão. O papel da burocracia e dos burocratas do alto escalão estadual no processo de produção de políticas públicas ainda permanece obscuro, no entanto, pois as pesquisas empíricas vêm se concentrando quase exclusivamente no estudo da burocracia federal (Olivieri, 2007, Schneider, 1994 , Loureiro, 1999).

Este trabalho se propõe a enfrentar questões ainda pouco exploradas ou que permanecem mal resolvidas na literatura, no que diz respeito à natureza dos processos de formulação e implementação de políticas públicas de gasto social na esfera dos estados, trazendo ainda evidências sobre o papel da burocracia e das nomeações de cargos do alto escalão nesses processos. A pesquisa empírica enfoca um conjunto de políticas públicas do setor de educação implementadas no estado da Bahia. O objetivo é mapear a distribuição intermunicipal dos investimentos realizada pela Secretaria Estadual na construção e reforma de escolas públicas no período 1999-2006, verificando a existência ou não de uma conexão entre as estratégias de investimentos e a dinâmica político-eleitoral. Para a análise dos investimentos estaduais em educação, adotou-se uma abordagem multimétodo, combinando análise estatística multivariada e descritiva com realização de entrevistas a informantes qualificados.

\section{BUROCRACIA, DINÂMICA POLITICO-ELEITORAL EPOLÍTICAS PÚBLICASNAESFERAESTADUAL}

Há uma ampla tradição de estudos sobre os retornos eleitorais das políticas públicas e sobre a relação entre ciclo político-eleitoral e formulação de políticas públicas. Em linhas gerais, os modelos da teoria da escolha racional partem do princípio de que os políticos são indivíduos autointeressados e racionais e que a formulação de políticas públicas atende aos imperativos de maximização de votos. Também se presume que os eleitores são motivados pelo autointeresse, sendo a decisão do voto afetada pelo cálculo dos custos e benefícios relativos das políticas públicas do ponto de vista do eleitor individual (Ames, 1987; Calvo e Murillo, 2004; Cox e McCubbins, 1986; Dahlberg e Johansson, 2002; Mayhew, 1974).

Uma das questões levantadas por essa literatura que é de pertinência para este trabalho é saber qual a lógica do cálculo político realizado pelo governo ao implementar determinadas políticas públicas. Um dos modelos formais que melhor resolve essa questão foi desenvolvido por Cox e McCubbins (1986). O pressuposto básico do modelo é de que os ocupantes de cargos públicos buscam, em suas estratégias de alocação de recursos, minimizar os riscos, recompensando os redutos eleitorais governistas com políticas de gasto público. A racionalidade por trás dessa estratégia é de que é mais fácil para o governo manter ou ampliar a sua votação nas áreas onde já possui apoio significativo do que tentar roubar votos da oposição ou ganhar o apoio das áreas de eleitorado volátil. Esse modelo prevê, portanto, que o formulador de políticas maximizador de votos irá concentrar recursos nos redutos (municípios) governistas, gastar pouco nos municípios de eleitorado volátil e menos ainda nos municípios de oposição.

Apesar da sofisticação teórica e metodológica dos modelos formais sobre a conexão eleitoral das políticas governamentais, deve-se notar que eles sofrem de algumas limitações analíticas importantes. A principal é que o argumento de que o ciclo político-eleitoral influencia a formulação e implementação de políticas públicas, embora intuitivamente poderoso, não é passível de aplicação a todo e qualquer tipo de políti ca pública. De fato, existe toda uma literatura da ciência política sobre "sub-governments", redes de política públi- 
ca e advocacy coalitions que demonstra como diferentes setores de política pública desenvolvem arranjos decisórios e redes de atores - burocratas, grupos de interesse e políticos - distintos e como essas redes de política pública, uma vez formadas, conseguem certa autonomia frente à macropolítica eleitoral (Baumgartner; Jones, 1993; Sabatier; Jenkins-Smith, 1999).

A literatura neoinstitucionalista, por sua vez, argumenta que os formuladores de políticas públicas não são motivados apenas pela maximização de votos, entre outras razões, porque os ocupantes de cargos públicos detêm certa autonomia frenteàs pressões dos eleitores e grupos sociais. A existência de burocracias regidas por princípios universalistas de contratação e promoção pode garantir, em alguns setores, certo insulamento do processo decisório frente às pressões político-partidárias (Evans, 1995; Skocpol, 1992). A questão, para essa literatura, é que as motivações dos atores estatais refletem, ao menos parcialmente, as posições institucionais que eles ocupam. Os representantes eleitos são mais sensíveis às pressões sociais e fatores eleitorais de curto prazo. $\mathrm{O}$ mesmo não se pode dizer de funcionários públicos e administradores dealto escalão, cuja ascensão ao cargo e possibilidades de avanço na carreira independem do apoio do eleitorado.

Quanto menor o grau de institucionalização da burocracia e da política pública, e quanto maior a politização das nomeações dos cargos de alto e médio escalão, tanto mais provável será verificarmos a prevalência da lógica da maximização eleitoral. Burocracias mais fortes e insuladas serão encontradas naqueles casos em que a contratação e a ascensão dos funcionários na organização se realizam com base no mérito e no tempo de serviço; além disso, parte significativa dos cargos do topo da hierarquia são reservados para preenchimento por funcionários de carreira, garantindo a coesão interna e a autonomia relativa do corpo burocrático. Deforma análoga, quanto maior a proporção de cargos abertos à nomeação de pessoas de fora da organização, maior será a probabilidade de a burocracia sofrer influências de interesses externos, por exemplo, de partidos e líderes políticos (Evans, 1995; Page, 1992; Silberman, 1993).

\section{Competição política, nomeações burocráticas e políticas públicas}

A questão das nomeações burocráticas adquire centralidade no caso brasileiro dado o baixo grau deinstitucionalizaçãoe alta porosidade organizacional das burocracias públicas. Em tal contexto, o insulamento da burocracia frente aos interesses externos irá depender quase sempre da força política do chefe do Executivo e da sua disposição de enfrentar os interesses políticos presentes no Legislativo e dentro do próprio aparelho burocrático. Instaurase, dessa forma, um processo não-institucionalizado de formulação de políticas públicas, no qual a formação de coalizões intraburocráticas de caráter informal, a partir da ocupação de postos-chave do aparelho burocrático, acaba por condicionar fortementea implementação dos planos e políticas governamentais (Schneider, 1994).

Outra peculiaridade do sistema político brasileiro é que as políticas públicas de responsabilidade dos estados têm grande importância para o desempenho eleitoral de candidatos a postos eletivos estaduais e nacionais. Dada a força do regionalismo e do federalismo na política brasileira, muitas decisões importantes relativas à vida eleitoral e partidária - a exemplo das convenções partidárias para a definição de candidaturas a quase todos os postos de expressão nacional, à exceção da presidência - são tomadas na esfera dos estados (Samuels, 2003). A associação entre a força eleitoral dos governadores e o desempenho de candidatos a cargos proporcionais tem como um dos seus componentes a capacidade do executivo estadual de formular e implementar políticas públicas de saúde, educação, infraestrutura, etc., exercendo controle sobre a nomeação de milhares de cargos e sobre a distribuição de verbas e realização de investimentos nos municípios.

Não se pode esquecer que a capacidade de formulação de políticas públicas pelo Poder Legislativo - seja na esfera nacional seja na esfera estadual - é bastante limitada, em virtude das prerrogativas institucionais que garantem ao chefe do Executivo poderes bastante amplos no que tange à 
formulação e implementação do orçamento, e o monopólio da iniciativa legislativa em matérias de ordemadministrativa, financeira e tributária (Figueiredo e Limongi, 1999; Figueiredo e Limongi, 2002). Em um sistema político no qual o centro de gravidade é o Poder Executivo (cf. Amorim Neto, 2007), a capacidade de os políticos instrumentalizarem eleitoralmente as políticas governamentais estará vinculada ao seu poder de influência, direto ou indireto, sobre o comportamento da burocracia.

\section{Política educacional e política eleitoral nos estados brasileiros}

Este trabalho investiga a conexão entre a dinâmica eleitoral, burocracia e gasto social a partir de um programa de construção e reforma de escolas públicas implementado pelo governo do estado da Bahia no período 1999-2006. As políticas públicas estaduais de educação constituem excelente material empírico para o exame dessas questões em virtude do papel central desempenhada por elas na política de patronagem nos estados. Deve-se lembrar que a função educação tem peso extremamente importante nos orçamentos dos estados, chegando a representar, em alguns casos, 1/3 do total da despesa, além de as Secretarias de Educação possuírem número elevado de funcionários efetivos e cargos de livre nomeação.

Talvez não por acaso, as verbas e cargos do setor educação eram (e são) utilizadas como recursos de barganha política, ferozmente disputados por prefeitos, deputados e líderes partidários. Uma vez submetidas à dinâmica da formação de coalizões partidárias em âmbito estadual, muitas Secretarias Estaduais de Educação terminavam por sofrer com elevados índices de rotatividade de pessoal e baixa eficiência operacional. Não raro, o cargo de secretário de educação servia de "trampolim eleitoral" para políticos em início de carreira ou para veteranos desejosos de incrementar sua votação e ascender a cargos de maior prestígio. Os titulares da pasta se aproveitavam do seu controle sobre o orçamento da educação e milhares de cargos de livre nomeação para incrementar suas perspectivas eleitorais futuras, recompensando eleitores, prefeitos e lideranças locais com a construção de novas escolas e com a distribuição de cargos nas escolas e diretorias regionais (Planck, 1996; Rocha, 2000; Souza, 1997).

Em que pese a longa tradição de manipulação político-eleitoral das políticas públicas educacionais, deve-se notar que, desde a constituição de 1988, vêm sendo obtidos avanços importantes no sentido de uma maior institucionalização dessas políticas, com a introdução de regras de financiamento e critérios de distribuição de recursos estabelecidos em lei (Castro et al., 2000; Cury, 2002; Hall, 2003). Outro aspecto é que, ao longo das últimas duas décadas, muitos estados da federação adotaram programas de reforma educacional no sentido de atacar os problemas de gestão e organização da educação básica (Barros e Mendonça, 1998; Borges, 2008; Rocha, 2000).

Apesar de algumas tendências no sentido da reversão de um padrão histórico de alta politização e baixa eficiência, cumpre notar que a área de educação ainda se caracteriza por um grau relativamente reduzido de institucionalização das burocracias setoriais e processos decisórios. Em paralelo às novas regras de distribuição de recursos públicos destinados ao financiamento da educação básica, persiste um padrão de gestão marcado pela baixa profissionalização das Secretarias Estaduais de Educação, rotatividade de pessoal de direção e falta de continuidade das políticas, além da ausência de mecanismos efetivos de responsabilização dos gestores estaduais e de avaliação das ações implementadas.

\section{O CASO DA SECRETARIA DE EDUCAÇÃO DO ESTADO DA BAHIA, 1999-2006}

O estado da Bahia se constitui, muito provavelmente, em um exemplo paradigmático da instrumentalização político-eleitoral das políticas educacionais. Pelo menos desde o regime burocrático-autoritário, a Secretaria Estadual de Educação 
foi utilizada por um mesmo grupo político, liderado pelo ex-governador e ex-senador Antônio Carlos Magalhães (ACM), como uma fonte de recursos de patronagem a serem trocados por votos e apoio político. Não por acaso, o desenvolvimento educacional do estado não acompanhou o rápido crescimento econômico vivenciado a partir dos anos 1970 com a implantação do Complexo Petroquímico de Camaçari. No início dos anos 2000, a Bahia detinha a maior economia industrial e o mais elevado Produto Interno Bruto (PIB) per capita da região Nordeste. Entretanto, as taxas de escolarização líquida (percentual de estudantes com idade adequada ao nível cursado) no ensino médio, em torno de $18 \%$, estavam entre as mais baixas de toda a região. O estado exibia ainda taxas bastante elevadas de analfabetismo funcional: cerca de $43 \%$ da população com 15 anos ou mais tinha menos de quatro anos de estudo. O sistema de educação estadual se caracterizava ainda por altas taxas repetência e distorção idade-série, de modo que, no ano de 1999, um estudante levava, em média, cerca de 11.2 anos para completar as 8 séries do ensino fundamental. ${ }^{2}$

No final dos anos 1990, o grupo político dominante do estado já demonstrava preocupação com a situação calamitosa do sistema público educacional. No ano de 1998, começou a ser desenvolvido, na Secretaria de Planejamento, Ciência e Tecnologia (SEPLANTEC) do estado um ambicioso programa de reforma educacional - "Educar para Vencer" - com o apoio de uma equipe de consultores que havia participado da concepção de reformas adotadas no início dos anos 1990 no estado de Minas Gerais. A ideia era dar total prioridade à área de educação na administração seguinte, que se iniciaria no ano de 1999. ${ }^{3}$

2 As fontes de dados consultadas foram o Atlas do Desenvolvimento Humano do PNUD, Censo 2000, Contas Regionais do Brasil de 2003 (IBGE), e o Anuário Estatístico da Educação - 1999, editado pelo governo do estado.

${ }^{3}$ Depoimentos concedidos ao autor por Ana Lúcia Castelo Branco (agosto 2003) e Robert Verhine (julho 2002). Naquele momento, o candidato da situação ao governo estadual era o deputado Luís Eduardo Magalhães, que acabou falecendo repentinamente em abril de 1998. Luís Eduardo foi substituído por César Borges, um político inexpressivo da região de Jequié, que acabou vencendo a eleição e assumindo o governo em 1999.
O programa gestado na SEPLANTEC e encampado pelo governo eleito em 1998 incluía medidas como a implementação de classes de aceleração para atacar a distorção idade-série, o fortalecimento da gestão das escolas e das secretarias municipais de educação, e a descentralização de recursos e autoridade para os conselhos escolares. Posteriormente, esse conjunto de ações foi acoplado a um outro projeto de reforma educacional - Projeto Bahia - financiado pelo Banco Mundial através de contrato de empréstimo firmado no início de 2000 (Bahia, 1999; World Bank, 2000; Xavier e Verhine, 2004).

O programa de expansão de rede física de escolas, especialmente do ensino médio, que será analisado em maior profundidade nesta seção, foi incluído no Projeto Bahia após negociação com o Banco Mundial. A princípio, a inclusão do subprojeto de expansão das vagas no ensino médio no projeto financiado enfrentou a oposição de técnicos do Banco, que acreditavam ser mais produtivo para o estado concentrar recursos na educação fundamental. ${ }^{4}$ No entanto, a Secretaria da Educação acabou vencendo essas resistências, de modo que o empréstimo serviu como fonte de recursos adicional para um programa de expansão do ensino médio que já vinha sendo implementado desde a gestão Paulo Souto (1995-1998).

O carro-chefe do plano de expansão do governo estadual era um programa de escolas-modelo, a serem construídas prioritariamente nos grandes centros urbanos do estado. Batizadas de "Colégios Luís Eduardo Magalhães - LEM -” em homenagem ao deputado do Partido da Frente Liberal (PFL) morto em 1998, os colégios-modelo tinham como um dos seus objetivos centrais aumentar a qualidade e a quantidade de vagas no ensino médio. Cada colégio LEM deveria dispor de infraestrutura de laboratório de ciências, quadra poliesportiva, sala de vídeo para ensino de língua estrangeira, além de um auditório de 200 lugares (Bahia, 1998). Além da expansão das vagas no ensino médio, a reforma educacional do

${ }^{4}$ Entrevistas concedidas ao autor por Edílson Souto Freire (abril 2003) em Salvador (BA). 
governo da Bahia propunha a ampliação e reordenamento da oferta de ensino fundamental, de modo a minimizar as desigualdades regionais. O programa financiado pelo Banco Mundial incluía um subprojeto, a ser financiado com recursos da contrapartida do estado, que visava à melhoria da infraestrutura dos prédios das escolas estaduais dos 100 municípios de menor desenvolvimento social e econômico do estado (Bahia, 2003, p. 33-39).

Nesse período, em que pesem os objetivos de “despolitização” da gestão educacional estabelecidos nos documentos oficiais do Banco Mundial e do governo do estado, a Secretaria da Educação foi chefiada por um político. O então governador César Borges nomeou para o cargo o deputado federal pelo PFL e ex-ministro da Educação do governo Collor, Eraldo Tinoco. O novo secretário ascendeu ao cargo, sobretudo na condição de um dos mais antigos e fiéis seguidores da mais importante liderança política do estado, o ex-governador Antônio Carlos Magalhães, cuja influência se fez sentir na formação de todo o secretariado de governo. O secretário Eraldo Tinoco não tardou a reconhecer a sua gratidão para com seu padrinho político, nomeando o então aspirante a deputado Antônio Carlos Magalhães Neto como um dos seus assistentes de gabinete. ${ }^{5}$

Outras nomeações que foram feitas pelo secretário também seguiram critérios políticos. Os cargos das diretorias regionais da educação, que atuavam como elos entre as escolas e a administração central, foram distribuídos entre prefeitos e deputados do grupo governista. Para a Superintendência de Coordenação Municipal, órgão responsável pela municipalização do ensino e realização de convênios com os municípios, o secretário indicou um sobrinho, o administrador de empresas Cláudio Melo. Essa era uma superintendência-chave, do ponto de vista da articulação política, ao assegurar um canal permanente de comunicação entre a SEC e as prefeituras onde seriam negociadas as demandas locais, muitas vezes a

Não é demais notar que o neto de ACM lograria se eleger deputado federal, como o $2^{\circ}$ mais votado da bancada baiana, ao final do governo César Borges. partir de critérios político-partidários. Para a Superintendência de Gestão Escolar (SUPEC), outro cargo estratégico da secretaria, também foi indicada uma pessoa da estrita confiança do secretário e integrante do seu círculo familiar. ${ }^{6}$ A SUPEC tinha grande importância do ponto de vista dos esquemas tradicionais de distribuição de patronagem na área de educação, sendo responsável pela alocação de suprimentos e manutenção das escolas. Além disso, essa superintendência tinha a atribuição de realizar estudos técnicos para embasar a tomada de decisão sobre a localização de novas escolas e (ou) salas de aula. ${ }^{7}$

Em outros casos, no entanto, o secretário Tinoco decidiu privilegiar a experiência e a competência técnica na escolha dos nomeados. Especialmente importante foi a nomeação de Renata Prosérpio, funcionária de carreira da Superintendência de Estudos e Estatísticas (SEI) do governo estadual, para a Superintendência de Diretrizes e Políticas Educacionais, órgão encarregado da coordenação de todos os subprojetos do programa Educar para Vencer. Em atendimento a um pedido do Banco Mundial, a administração do projeto foi delegada para uma unidade administrativa especial da SEC, a Coordenação de Projetos Especiais (COPE), que havia sido criada para administrar os projetos educacionais financiados por fontes externas. Seguindo a experiência de outros projetos do Banco, foi contratada toda uma equipe de funcionários externos à SEC para gerenciar as ações do Projeto Bahia, com remuneração bastante superior àquela dos funcionários do quadro permanente. O recrutamento de pessoal para a unidade foi coordenado pelo staff do Banco e, até onde foi possível ao autor investigar, não houve interferência do secretário ou dos partidos governistas na contratação. ${ }^{8}$

${ }^{6} \mathrm{O}$ nomeado era sobrinho da esposa de Eraldo Tinoco.

${ }^{7}$ O papel central desempenhado pela SUPEC nas decisões de localização das obras da SEC foi enfatizado nas entrevistas concedidas ao autor por Antônio Mário Sousa (abril 2008), Eliana Carvalho (fevereiro 2008) e Arturo Catunda (julho 2008). Os dois últimos entrevistados enfatizaram ainda que nem sempre as recomendações dos estudos técnicos eram seguidas fielmente, em virtude de pressões políticas para a construção de escolas em determinadas localidades.

${ }^{8} \mathrm{O}$ mesmo ponto de vista é defendido por Xavier e Verhine (2004), com base em entrevistas realizadas com integrantes da equipe do projeto e do quadro permanente da secretaria. 
Como seria de se esperar, a convivência entrea ala "técnica" e a ala "política" da secretaria gerou diversos pontos de atrito na implementação dos projetos, uma vez que o secretário Tinoco e seus apadrinhados tinham objetivos que não necessariamente coincidiam com aqueles estabelecidos pelo Banco Mundial, pela COPE e pela Superintendência de Diretrizes e Políticas Educacionais. ${ }^{9}$ Um dos pontos de conflito surgiu quando da implementação do subprojeto de melhoria dos prédios escolares egarantia de padrões mínimos de funcionamento nos municípios mais pobres do estado. A proposta do Banco Mundial era integrar o subprojeto a um programa mais amplo de combate à pobreza da SEPLANTEC, o "Faz Cidadão", que propunha uma série de ações sociais integradas, envolvendo diversas secretarias estaduais nos 100 municípios de menor desenvolvimento econômico e social da Bahia (World Bank, 2000). Entretanto, o secretário não aceitava a lista de 100 municípios definida com base em um índice de desenvolvimento social. Como resultado, o Banco Mundial e a SEC trabalharam inicialmente com programas de investimento paralelos, sendo que o programa da secretaria selecionou os municípios com base em critérios político-partidários (Xavier e Verhine, 2004).

No que diz respeito ao programa de expansão de vagas do ensino médio, o Projeto Bahia tinha como uma de suas diretrizes garantir a máxima eficiência na distribuição dos recursos, através de estudos das condições de oferta e demanda por educação nos municípios. O documento oficial do projeto afirmava que a construção de novas classes e ou escolas só seria realizada quando não fosse possível ampliar as vagas por meio da otimização da infraestrutura existente ou quandoficasse clara a existência de uma demanda potencial capaz de justificar novos investimentos. Além disso, o projeto propunha conferir maior prioridade à ampliação de escolas já existentes, garantindo menores custos (World Bank, 2000, p. 10-11). ${ }^{10}$

\footnotetext{
${ }^{9}$ Entrevistas concedidas por Jansen Teixeira (julho 2002 abril 2008), Arturo Catunda (julho de 2008), Robert Verhine (julho de 2002) e Renata Prosérpio (junho 2003) em Salvador (BA).

${ }^{10}$ É importante notar que o Banco Mundial não aceitou financiar o programa de escolas-modelo Luís Eduardo Magalhães. O projeto previa que a realização desses investimentos seria coberta com recursos da contrapartida do governo estadual.
}

Também nesse caso, as intenções da equipe do Projeto Bahia se chocavam com a prática política tradicional, tendo em vista o importante impacto eleitoral de obras de construção de escolas nos municípios. Para o prefeito ou parlamentar com base no município, a obtenção do crédito pela construção de uma escola no seu reduto eleitoral se afigura como uma oportunidade valiosa de "mostrar serviço" junto ao eleitorado e, assim, maximizar suas chances eleitorais futuras. Não se pode esquecer ainda que a construção de uma nova escola implica a criação de um número significativo de empregos públicos, muitos dos quais são loteados entre deputados e lideranças locais. ${ }^{11}$

Do ponto de vista do executivo estadual, a utilização de critérios político-partidários na alocação de investimentos serve ao objetivo de premiar os prefeitos governistas e punir os oposicionistas, negando-lhes acesso aos recursos, e, assim, assegurar uma ampla base de apoio na esfera local. Como observam Samuels (2003) e Abrucio (1998), os prefeitos e lideranças locais atuam como intermediários entre o governo estadual e os eleitores, em especial nos municípios mais pobres, de modo que a política de cooptação das prefeituras joga papel importante na construção de coalizões eleitorais nos estados.

Políticos de oposição entrevistados pelo autor relataram que a administração municipal dos seus partidos não conseguiu firmar nenhum convênio com a SEC para transferência de recursos ou cooperação técnica ao longo de toda a gestão Eraldo Tinoco, e mesmo nas gestões posteriores. Em todos os casos, a relação entre as prefeituras oposicionistas e as diretorias regionais de educação da SEC, responsáveis pela articulação entre os municípios e a administração central, era marcada pela absoluta indiferença quando não pela hostili-

${ }^{11}$ Deve-se notar que boa parte dos pequenos municípios do estado tem economias frágeis e fortemente dependentes da atividade governamental, o que favorece o estabelecimento de relações clientelistas. Em entrevista concedida ao autor em março de 2008, a deputada estadual e ex-prefeita Neusa Cadore observou que há casos de famílias inteiras que dependem de empregos precários nas escolas (como merendeira, porteiro, etc.), preenchidos com base em indicações políticas. No momento da eleição, o alinhamento com o político responsável pela nomeação torna-se, assim, questão de sobrevivência. 
dade aberta. ${ }^{12}$ Segundo os depoimentos colhidos, as secretarias municipais e os órgãos estaduais de educação trabalharam de forma descoordenada e competitiva nos municípios oposicionistas, de modo que, em muitos casos, o governo local foi obrigado a atender às demandas da população por escolarização contando apenas com recursos próprios e com as transferências do governo federal.

Concluindo, pode-se dizer que, ao longo do período em análise, coexistiam, dentro da SEC, lógicas antagônicas. De um lado, uma lógica burocrática que privilegiava a definição de critérios objetivos e universalistas de distribuição de recursos, com vistas ao atendimento de metas de eficiência e equidade. Do outro, uma lógica político-partidária, amparada no particularismo e voltada para a maximização da "eficiência eleitoral” dos gastos públicos. Na seção seguinte, são apresentados os resultados desse embate a partir da análise estatística dos gastos da SEC no período 1999-2002. Análise do programa de expansão da rede fí-
sica de escolas, 1999-2002

A Tabela 1 traz dados descritivos dos investimentos realizados pela SEC no período 1999-
2002. Como se pode depreender dos dados, a maior parte dos recursos (cerca de 60\%) foi destinada ao ensino médio. Quando se observam os percentuais por tipo de obra, a construção de novas escolas de ensino médio tem a maior participação em relação ao total: 44,68\%. No caso do ensino fundamental, as obras de recuperação de escolas representam as rubricas de maior peso: $26 \%$ do total geral e $66 \%$ do total destinado a esse nível de ensino.

A distribuição dos recursos investidos reflete claramente a prioridade conferida pelo governo estadual ao ensino médio e, em especial, à construção de colégios-modelo. Ao longo do período 1999-2002, foram construídas 25 novas escolasmodelo Luís Eduardo Magalhães, de um total de 55 escolas de ensino médio. Devido ao seu porte (capacidade para 2.400 alunos cada), todas as novas escolas-modelo foram construídas na capital e em centros regionais como Feira de Santana, Jequié e Vitória da Conquista.

Para estimação do impacto de fatores político-partidários, sociais e demográficos sobre a distribuição intermunicipal dos gastos, utilizou-se um modelo de regressão logística. A variável dependente foi codificada como uma variável dummy, sendo que os municípios que receberam investimentos assumiram valor 1 e os municípios que não receberam

Tabela 1 - Bahia: Gastos Estaduais em Expansão e Melhoria da Rede de Escolas Públicas Estaduais, por Tipo de Obra e Nível de Ensino, 1999-2002

\begin{tabular}{|c|c|c|c|c|c|c|}
\hline \multirow[b]{2}{*}{ Tipo de Obra } & \multicolumn{2}{|c|}{ 1999-2000 (A) } & \multicolumn{2}{|c|}{ 2001-2002 (B) } & \multicolumn{2}{|c|}{$(A+B)$} \\
\hline & $\begin{array}{l}\text { Total investido } \\
\text { (R\$ mil) }\end{array}$ & $\%$ Total & $\begin{array}{l}\text { Total investido } \\
\text { (R\$ mil) }\end{array}$ & $\%$ Total & $\begin{array}{l}\text { Total investido } \\
\text { (R\$ mil) }\end{array}$ & $\%$ Total \\
\hline Construção/Ens. Fundamental & 10.848 & 13 & 12.830 & 11 & 23.678 & 12 \\
\hline Construção/Ens. Médio & 45.603 & 53 & 43.467 & 38 & 89.070 & 45 \\
\hline Construção/Ens. Profis. & 0 & 0 & 1.501 & 1 & 1.501 & 1 \\
\hline Ampliação/Ens. Fundamental & 2.279 & 3 & 809 & 1 & 3.088 & 2 \\
\hline Ampliação/Ens. Médio & 0 & 0 & 6.733 & 6 & 6.733 & 3 \\
\hline Recuperação/Ens. Fundamental & 25.836 & 30 & 27.165 & 24 & 53.001 & 27 \\
\hline Recuperação/Ens. Médio & 1.322 & 2 & 19.554 & 17 & 20.876 & 10 \\
\hline Construção/ Quadra Poliesp. & 47 & 0 & 1.058 & 1 & 1.105 & 1 \\
\hline Sub-total - Ens. Fundamental & 38.963 & 45 & 40.804 & 36 & 79.767 & 40 \\
\hline Sub-total Ensino Médio & 46.925 & 54 & 71.255 & 63 & 118.180 & 59 \\
\hline Total Geral & 86.205 & 100 & 113.117 & 100 & 199.322 & 100 \\
\hline \multicolumn{7}{|l|}{ Fontes: Bahia (2003; 2001) } \\
\hline
\end{tabular}


nenhum recurso, valor zero. A utilização de uma variável dependente categórica se justifica tendo em vista o propósito da análise, que é determinar o porquê da focalização de investimentos em determinado grupo de municípios, e não explicar diferenças individuais no nível de gasto por município. Além disso, deve-se notar que o número de municípios que receberam recursos ao longo dos biênios 1999-2000 e 2001-2002 é pequeno relativamente ao total (82 entre 1999 e 2000 e 163 entre 2001 e 2002, de um total de 413 casos válidos), de modo que a análise intervalar (ex. com a aplicação da técnica de regressão linear) seria pouco adequada em virtude da forte assimetria das distribuições.

Com o objetivo de maximizar o número de casos, os dados de gasto para cada um dos biênios foram empilhados. Considerando a perda de quatro casos dos 417 municípios do estado, chegou-se a um total de 826 casos válidos. ${ }^{13}$ Esse procedimento se revelou especialmente útil para garantir a correta mensuração de uma variável-chave da análise: a orientação partidária do prefeito. Novos prefeitos foram eleitos em 2000 e tomaram posse em 2001. O empilhamento das séries agrupadas por biênio permitiu que essa mudança fosse incorporada às variáveis binárias de filiação partidária do executivo local: as primeiras 413 observações dessas variáveis indicam a filiação partidária em 1999 (prefeitos eleitos em 1996) e as 413 seguintes a filiação em 2001 (prefeitos eleitos em 2000).

O modelo de regressão logística foi especificado tendo em mente o objetivo de estimar a magnitude do impacto de fatores político-partidários sobre a alocação de recursos, controlando o impacto de critérios hipotéticos de equidade e capacidade. Como indicadores da capacidade dos municípios, foram utilizadas quatro variáveis. Como proxies da demanda por escolarização, população (população) e participação da força de trabalho na indústria (trab_indústria), ambas transformadas em seus logaritmos, por conta da assimetria nas distribui-

${ }^{13}$ No período imediatamente posterior ao Censo 2000, foram criados dois municípios (Luís Eduardo Magalhães e Barrocas), por emancipação dos municípios de Barreiras e Serrinha, respectivamente. Por conta dessa mudança, perderam-se as informações para quatro casos de um total de 417 municípios. ções (dados relativos ao ano 2000). Considerando a concentração dos gastos no nível médio de ensino, seria de se esperar que os grandes centros urbanos, onde é maior a demanda pelos níveis mais altos de escolarização, recebessem mais recursos vis-à-vis os municípios pequenos. Como indicadores do grau de cobertura e extensão da rede de ensino básico, utilizou-se a taxa de escolarização líquida no nível fundamental no ano de 2000 (esc fundamental) e o total de escolas estaduais de ensino médio no município no ano de 1999 (escolas_EM), sendo essa última variável transformada em seu logaritmo. ${ }^{14}$ Teoricamente, municípios que possuem uma rede já consolidada estariam em melhores condições de receber novos investimentos (ex. em recuperação e ampliação de salas). Além disso, quanto maior a taxa de escolarização fundamental e o total de escolas de nível médio, tanto maior deveria ser a demanda potencial por escolarização.

Como indicador de equidade foi criada uma variável binária que identifica os 100 municípios de menor desenvolvimento social e econômico do estado (mun_pobres), seguindo critérios adotados pela SEI, órgão ligado à Secretaria do Planejamento do governo estadual (World Bank, 2000). Na medida em que o programa de expansão e melhoria da rede de ensino propunha a focalização de parte dos recursos nesses municípios, poder-se-ia supor que a probabilidade de eles obterem investimentos seria superior à de todos os demais municípios, ceteris paribus.

As variáveis de contexto político incluem uma variável dummy, indicando a presença ou ausência (1/0) de um prefeito filiado ao PFL no município (PFL), além de uma variável que indica a presença ou ausência de prefeitos cujos partidos participaram da coligação que elegeu o governador em 1998 (pref_coligação). ${ }^{15}$ Adicionalmente, foi

${ }^{14}$ Decidiu-se utilizar o número de escolas de nível médio e não de nível fundamental como indicador de capacidade para receber investimentos, porque a maioria das escolas e obras realizadas no período se destinavam à expansão do nível médio.

${ }^{15}$ Os partidos que participaram da coligação que elegeu César Borges em 1998 e também elegeram prefeitos em 1996 e 2000 são os seguintes: PP, PTB, PL e PMDB. O PMDB foi excluído da variável, no entanto, pois esse partido rompeu com o governador no meio do mandato. 
criada uma dummy para os prefeitos de oposição, representando a soma do total de prefeitos eleitos pelos partidos de oposição ao governo estadual em 1996 e $2000 .{ }^{16}$ Essa última variável acabou sendo retirada do modelo, no entanto, em razão de problemas de colinearidade com as demais dummies de orientação partidária dos prefeitos. $\mathrm{O}$ modelo estimado somente com as variáveis PFL e pref_coligação mostrou ter maior poder explicativo, o que justificou a exclusão.

Por fim, a variável vt_secretário indica os municípios onde o secretário Eraldo Tinoco concentrou a sua votação nas eleições para deputado federal de 1998. A inclusão dessa variável tinha como objetivo verificar até que ponto as decisões de alocação de investimentos da Secretaria da Educação teriam beneficiado os redutos eleitorais do secretário. O percentual de votos válidos obtidos pelo secretário em cada município foi recodificado como uma variável binária, que indica os municípios onde a votação foi igual ou superior a $20 \%$. Estabeleceu-se esse limite através da análise descritiva da distribuição da votação: cerca de $80 \%$ do total de votos foram obtidos em um total de 56 municípios onde a votação foi maior ou igual a $20 \%$. O restante da votação acabou dispersa por um grande número de municípios, a grande maioria de votação marginal (inferior a $5 \%$ do total). Ainda que o procedimento de codificação adotado seja, em certa medida, arbitrário, é preciso notar que a utilização de uma variável binária facilita a interpretação dos coeficientes da regressão logística e a estimação de probabilidades a partir dos mesmos. Além disso, não se observaram diferenças significativas do ponto de vista do poder explicativo entre um primeiro modelo estimado com uma variável intervalar (\% de votos válidos do secretário) e o modelo com a variável binária.

${ }^{16}$ Foram incluídos apenas os maiores partidos da oposição de centro (PMDB e PSDB) e esquerda (PT, PSB, PDT, PPS e PC do B). Por falta de informações confiáveis sobre o posicionamento dos micro-partidos sem representação na assembleia, além do pequeno número de prefeitos eleitos, estes não foram incluídos.
A Tabela 2 mostra os resultados do modelo de regressão logística estimado com as variáveis independentes descritas acima.

- Modelo de regressão logística para investimentos educacionais, 1999-2002 \begin{tabular}{|c|c|c|}
\hline & B & Erro \\
\hline
\end{tabular}

\begin{tabular}{|c|c|c|c|c|c|}
\hline Variáveis & B & Erro & Wald & Sig. & $\operatorname{Exp}(B)$ \\
\hline população & 1,698 ** & 0,372 & 20,824 & 0,000 & 5,461 \\
\hline trab_indústria & $0,516^{*}$ & 0,248 & 4,323 & 0,038 & 1,675 \\
\hline esc_fundamental & $0,046^{*}$ & 0,023 & 3,861 & 0,049 & 1,047 \\
\hline escolas_EM & $1,261^{*}$ & 0,505 & 6,231 & 0,013 & 3,530 \\
\hline mun_pobres & 0,083 & 0,199 & 0,174 & 0,676 & 1,086 \\
\hline $\mathrm{PFL}$ & 0,579 ** & 0,216 & 7,202 & 0,007 & 1,784 \\
\hline pref_coligação & 0,176 & 0,203 & 0,750 & 0,386 & 1,192 \\
\hline vt_secretário & 0,889 ** & 0,230 & 14,933 & 0,000 & 2,434 \\
\hline Constante & $-13,369$ & 2,805 & 22,720 & 0,000 & 0,000 \\
\hline
\end{tabular}

Como esperado, o impacto dos indicadores de capacidade é positivo e significativo, como destaque para os indicadores de população e total de escolas de ensino médio (escolas_EM). O modelo indica que o porte populacional do município, a importância das atividades industriais e o grau de desenvolvimento da rede de educação fundamental e média estão associados positivamente à realização de investimentos educacionais. Por sua vez, o indicador de equidade (mun_pobres) não apresenta relação significativa com a variável dependente.

O comportamento das variáveis políticopartidárias, de um modo geral, também atende às expectativas hipotéticas. A variável dummy para os prefeitos do PFL obteve coeficiente positivo e significativo, indicando que os municípios governados pelo partido foram privilegiados na alocação de recursos. Já o coeficiente para o indicador dos prefeitos coligados (pref_coligação) não se mostrou significativo, ainda que positivo como previsto. Muito provavelmente, há uma explicação simples para a diferença observada entre essas duas variáveis: o então secretário da educação era filiado ao PFL, de modo que não seria de se estranhar um privilégio nos municípios governados pelo partido vis-à-vis as prefeituras dos demais partidos da base aliada. O que não quer dizer que as prefeituras dos partidos coligados não tenham sido signi- 
ficativamente beneficiadas com recursos ao longo do período. Uma simples análise descritiva mostra que, em média, ao longo do período 1999-2002, as prefeituras do PFL receberam R\$ $5.68 \mathrm{em}$ investimentos per capita, as prefeituras coligadas $R \$$ 4.51 e as prefeituras de oposição, $R$ \$ 3.92. A média geral para todos os casos é de $\mathrm{R} \$ 4.80$.

A variável dummy para os redutos eleitorais do secretário Eraldo Tinoco se mostrou fortemente significativa e positiva. Esse resultado indica que, ao longo do período 1999-2002, o secretário e então deputado federal licenciado buscou recompensar a sua base eleitoral com a realização de obras de recuperação, ampliação e construção de escolas.

Os resultados nos levam a inferir que, ao longo do período estudado, a Secretaria combinou critérios técnicos e políticos nas decisões de alocação de recursos. Ou seja, ainda que os municípios com maior capacidade de receber investimentos tenham sido mais beneficiados, independentemente de quaisquer outros fatores, pode-se concluir que os recursos foram concentrados em municípios que não só apresentavam indicadores de capacidade elevados, mas também atendiam a critérios político-partidários.

\section{Análise do programa de expansão da rede fí- sica de escolas, 2003-2006}

No período que vai de 2003 a 2006, a Secretaria da Educação teve duas dirigentes: Renata Prosérpio, nos meses de janeiro a março de 2003, e Anaci Paim, no período de abril de 2003 até o final de 2006. A primeira, como já visto no início desta seção, era funcionária de carreira da SEI, e havia sido nomeada Superintendente de Políticas e Diretrizes Educacionais na gestão Eraldo Tinoco. A professora Anaci Paim ocupava o cargo de reitora da Universidade Estadual de Feira de Santana (UEFS), tendo uma trajetória marcadamente acadêmica até o convite para dirigir a Secretaria da Educação.

A rápida passagem de Renata Prosérpio pela secretaria pode ser descrita como a ascensão e a queda de um modelo de gestão tecnocrático, incompatível com a acomodação das demandas particularistas do clientelismo miúdo que, tradicionalmente, haviam moldado as políticas educacionais do estado. A secretária nomeada pelo governador Paulo Souto em janeiro de 2003 procurou privilegiar a competência técnica na nomeação dos cargos de $1^{\circ}$ escalão, montando sua equipe com líderes e coordenadores que haviam se destacado durante a implementação da $1^{\text {a }}$ fase do Projeto Bahia, a exemplo da Superintendente de Educação Básica, Nádia Viana Rodrigues, e o Superintendente de Políticas, Diretrizes e Avaliação Educacional, Domingos Barbosa Neto. A Superintendência de Gestão Escolar (SUPEC) e a Superintendência de Articulação Municipal (SUPAM) foram ocupadas por funcionárias de carreira da Secretaria da Educação, o que evidencia uma preocupação em evitar a submissão das decisões do órgão a interesses externos, de caráter político-partidário.

Diferentemente do seu antecessor, a secretária Renata Prosérpio tinha o objetivo determinado de garantir a prevalência de critérios universalistas na tomada de decisões da Secretaria da Educação, o que estava explícito no plano estratégico apresentado à sua equipe (Bahia, 2003b). Uma das suas primeiras medidas foi mandar de volta para a sala de aula dezenas de professores da rede ensino estadual que haviam sido nomeados para posições administrativas do baixo escalão da secretaria, muitas vezes se valendo de contatos pessoais com políticos influentes. Além disso, a gestão de Renata Prosérpio se caracterizou pela tentativa de seguir de forma estrita a legislação estadual que exigia que os nomeados ao cargo de direção e vice-direção das escolas públicas estaduais tivessem sido previamente aprovados em um teste de conhecimentos padronizado. Não surpreendentemente, essas e outras medidas provocaram reações de contrariedade nos meios políticos governistas.

Em março de 2003, apenas três meses após o início do mandato, a secretária Renata Prosérpio pediu exoneração do cargo. Segundo a versão oficial, a renúncia teria sido motivada em razão de doença; entretanto, informações veiculadas pela 
mídia e por analistas políticos dão conta de que a saída seria decorrência da insatisfação de prefeitos e deputados governistas com o tratamento dispensado pela secretária. ${ }^{17}$

Poucos meses depois, assumiu o cargo a então reitora da UEFS, Anaci Bispo Paim. Inicialmente, a nova secretária manteve a maior parte da equipe montada por Renata Prosérpio, mas, ao longo do $1^{\circ}$ e $2^{\circ}$ ano da sua gestão, foram feitas modificações nas Superintendências de Ensino, e Diretrizes e Políticas Educacionais. Foram mantidas nos cargos as Superintendentes de Atendimento à Rede Escolar e de Articulação Municipal. No período, os cargos de alto escalão da Secretaria da Educação foram ocupados, em sua maioria, por funcionários de carreira da secretaria, ou por gestores recrutados entre os quadros acadêmicos da UEFS. É também digna de nota a extinção da Superintendência de Articulação Municipal (SUPAM) em janeiro de 2004. ${ }^{18}$ Ao longo da gestão Eraldo Tinoco, o órgão tinha desempenhado o papel de intermediar as demandas dos prefeitos, de modo que a sua extinção sinalizava um relativo fechamento da burocracia setorial frente às pressões político-partidárias locais.

Apesar de não ter experiência prévia na política eleitoral, nem vínculos partidários, a secretária Anaci Paim tinha bom trânsito junto ao grupo político então dominante no estado. Além disso, a ex-reitora da UEFS procurou, ao longo da sua gestão, priorizar ações de grande visibilidade e apelo eleitoral - especialmente a construção de escolas de ensino médio no interior do estado.

A preferência pela construção de novas escolas contrariava as diretrizes defendidas pelo Banco Mundial e pelos técnicos do projeto, que pregavam uma maior destinação de recursos para a ampliação e reorganização da rede de escolas já existente, garantindo a máxima eficiência dos investimentos. Deve-se notar que o projeto de educação

${ }^{17}$ A exemplo de notícia veiculada no jornal A Tarde de 20 de março de 2003, que traz depoimentos anônimos sobre a insatisfação de deputados estaduais com os critérios para escolha de diretores de escolas estaduais.

${ }^{18}$ Lei n. 8970 de 6 de janeiro de 2004. É importante notar, entretanto, que a SUPAM já havia sido, na prática, desativada desde a gestão de Renata Prosérpio, segundo informações obtidas em entrevistas. financiado pelo Banco tinha como um dos seus pressupostos a ideia de priorizar o aumento da qualidade da rede de ensino existente, investindo em ações como a correção da distorção idade-série. Entretanto, a secretaria Anaci Paim não tinha interesse em dar continuidade às ações iniciadas na gestão Eraldo Tinoco, uma vez que a sua agenda de política educacional não necessariamente coincidia com os objetivos do Projeto Bahia e do programa Educar para Vencer. ${ }^{19}$ A falta de sintonia entre a secretária e a equipe técnica contratada pelo Banco Mundial foi mencionada explicitamente em um relatório de avaliação sobre a $2^{\mathrm{a}}$ fase do Projeto Bahia. Fugindo ao tom normalmente comedido dos documentos oficiais do Banco, o relatório cita a "falta de comprometimento institucional" do $1^{\circ}$ escalão da Secretaria da Educação ao longo da gestão Anaci Paim, como um fator negativo para a implementação do projeto (World Bank, 2007, p. 7).

Há indícios de que a secretária possuía ambições políticas que iam além do alto escalão estadual. Nas eleições municipais de 2008, dois anos após o final do seu mandato, a professora Anaci Paim tentou se viabilizar, sem sucesso, como candidata à vice-prefeitura de sua cidade natal, Feira de Santana, na chapa encabeçada pelo deputado estadual pelo Democratas (antigo PFL), Tarcízio Pimenta. Vale observar também que o filho da então secretária logrou eleger-se vereador em Feira de Santana nas eleições municipais de 2004, pelo PFL. Talvez não por acaso, a cidade natal da secretária Anaci Paim obteve o $2^{\circ}$ lugar dentre todos os municípios no que diz respeito ao total de recursos investidos pelo programa de expansão e melhoria da rede física de escolas no período 2003-2006, logo atrás da capital do estado, Salvador. ${ }^{20}$

O programa de construção, ampliação e reforma de escolas assumiu, ao longo da gestão Anaci Paim, caráter mais marcadamente redistributivo, pois

\footnotetext{
${ }^{19}$ Este ponto foi citado por Jansen Teixeira e Nádia Viana Reis em entrevistas concedidas ao autor.

${ }^{20}$ No período 2003-2006, os investimentos realizados em Feira de Santana totalizaram $\mathrm{R} \$ 1,8$ milhões contra cerca de R\$ 15 milhões recebidos pela cidade de Salvador. Na gestão anterior (1999-2002), o município de Feira de Santana não obteve colocação entre os 10 municípios com maior volume de investimentos recebidos.
} 
um dos seus objetivos passou a ser a garantia de acesso ao ensino médio em todos os municípios do estado, com a construção de escolas na zona rural e em municípios não atendidos pela rede estadual. Como resultado dessas diretrizes, ao final do ano de 2006, a rede de escolas de ensino médio atendia a 415 dos 417 municípios do estado, contra um total de 345 municípios em 2002. Em entrevista ao autor, a secretária justificou a política de construção de escolas adotada no período como decorrente da necessidade de facilitar o acesso ao ensino médio e reduzir a evasão escolar. Isso porque, nas localidades mais remotas, que distam da sede do município, é comum o aluno precisar percorrer dezenas de quilômetros para estudar todos os dias, o que dificulta a permanência na escola. ${ }^{21}$

A Tabela 3 mostra a distribuição dos investimentos da Secretaria da Educação no período 2003-2006, por tipo de obra e nível de ensino.

Assim como no período 1999-2002, é evidente a prioridade conferida ao ensino médio, especialmente à construção de escolas desse nível de ensino. No total, essa rubrica absorveu cerca de metade (49\%) de todos os recursos investidos en- tre 2003 e 2006. Ao longo do mesmo período, os investimentos na ampliação da rede instalada do ensino fundamental foram significativamente inferiores, o que reflete a política de municipalização desse nível de ensino.

Apesar de louvável em teoria, o esforço de redução das desigualdades intermunicipais no acesso ao ensino médio via construção de novas escolas resultou em problemas de ineficiência alocativa, uma vez que muitas escolas foram construídas em locais onde não havia demanda suficiente para justificar tal investimento. ${ }^{22}$ De fato, no mesmo período em que a Secretaria da Educação buscava expandir a rede, aumentando a capacidade instalada, o total de matrículas no ensino médio no estado experimentou tendência de queda, contribuindo para aumentar a ociosidade das escolas em alguns municípios. A título de exemplo, somente nos anos de 2003 e 2004, foram abertas mais 110.000 vagas nas escolas de ensino médio estadual, como resultado da construção e ampliação de escolas e reordenamento da rede (Bahia, 2006, p. 24). Entretanto, ao longo do quadriênio 2003-2006, houve uma perda de 30.000 matrícu-

Tabela 3 - Bahia: Gastos Estaduais em Expansão e Melhoria da Rede de Escolas Públicas Estaduais, por Tipo de Obra e nivel de ensino, 2003-2006

\begin{tabular}{|c|c|c|c|c|c|c|}
\hline \multirow[b]{2}{*}{ Tipo de Obra } & \multicolumn{2}{|c|}{ 2003-2004 (A) } & \multicolumn{2}{|c|}{ 2005-2006 (B) } & \multicolumn{2}{|c|}{$(A+B)$} \\
\hline & $\begin{array}{c}\text { Total investido } \\
\text { (R\$ mil) }\end{array}$ & $\%$ Total & $\begin{array}{l}\text { Total investido } \\
\text { (R\$ mil) }\end{array}$ & $\%$ Total & $\begin{array}{l}\text { Total investido } \\
\text { (R\$ mil) }\end{array}$ & $\%$ Total \\
\hline Construção/Ens. Fundam. & 3.523 & 8 & 1.126 & 2 & 4.649 & 5 \\
\hline Construção/Ensino Médio & 18.901 & 42 & 29.937 & 55 & 48.838 & 49 \\
\hline Construção / Ens. Profission. & 203 & 0 & 0 & 0 & 203 & 0 \\
\hline Ampliação / Ens.Fundam. & 217 & 0 & 247 & 0 & 464 & 0 \\
\hline Ampliação / Ensino Médio & 4.264 & 9 & 347 & 1 & 4.611 & 5 \\
\hline Recuperação / Ens. Fundam. & 10.858 & 24 & 10.107 & 18 & 20.965 & 21 \\
\hline Recuperação/Ensino Médio & 6.147 & 14 & 12.555 & 23 & 18.702 & 19 \\
\hline Construção/Q.Poliesportiva & 993 & 2 & 409 & 1 & 1.402 & 1 \\
\hline Sub-total Ens. Fundamental & 14.599 & 32 & 11.480 & 21 & 26.079 & 26 \\
\hline Sub-total Ensino Médio & 29.312 & 65 & 42.839 & 78 & 72.151 & 72 \\
\hline Total Geral & 45.107 & 100 & 54.728 & 100 & $99.835,00$ & 100 \\
\hline
\end{tabular}

Fonte: Relatórios Anuais da SUCAB.

21 Depoimento concedido por Anaci Bispo Paim em setembro de 2008
22 Entrevista concedida ao autor por Eliana Carvalho em fevereiro de 2008. A entrevistada afirmou que as decisões sobre a localização de novas escolas foram tomadas não raro com base em critérios político-partidários. Por sua vez, Jansen Teixeira relatou ter visitado escolas construídas no período que apresentavam taxas elevadas de ociosidade (entrevista realizada em abril de 2008). 
las na rede estadual do nível médio. ${ }^{23}$ Como se vê redistributivos, uma vez que não existiam estudos na Tabela 4, a taxa de ocupação da rede estadual técnicos de projeção da demanda por esse nível (total dos níveis fundamental e médio) caiu de $90 \%$ de ensino que embasassem tais investimentos. ${ }^{27}$ em 2003 para cerca de $70 \%$ em 2006: $:^{24}$

A priorização do investimento em construção de novas escolas também pode-

Tabela 4 - Bahia - Demonstrativo da ocupação x capacidade física instalada da rede ensino estadual (fundamental e médio), 2003-2006

\begin{tabular}{l|c|c|c|c}
\hline & $\mathbf{2 0 0 3}$ & $\mathbf{2 0 0 4}$ & $\mathbf{2 0 0 5}$ & $\mathbf{2 0 0 6}$ \\
\hline Capacidade instalada (A) & 2.085 .446 & 1.959 .387 & 1.926 .110 & 1.970 .446 \\
\hline Ocupação (B) & 1.886 .758 & 1.588 .526 & 1.561 .278 & 1.374 .663 \\
\hline (A / B) & 90,47 & 81,07 & 81,06 & 69,76 \\
\hline
\end{tabular}

Fonte: Bahia (2006)

Deve-se observar que a tendência de queda nas matrículas do ensino médio se manteve em anos posteriores, o que sugere não se tratar de um fenômeno de caráter conjuntural. Os dados mais recentes do INEP mostram que, entre os anos de 2007 e 2009, a rede estadual perdeu cerca de 13.000 matrículas. ${ }^{25}$ É preciso notar, por outro lado, que as taxas de atendimento, que indicam o percentual da população em idade escolar apropriada (no caso do ensino médio, de 15 a 17 anos) que frequenta a escola, experimentaram queda significativa entre 2002 e 2006, de $91.2 \%$ para 78.6\% ${ }^{26}$ Isso indica que uma parcela significativa da população jovem do estado não frequenta e (ou) abandona a escola a partir de certa idade, o que sugere haver ainda uma significativa demanda potencial não atendida. Feitas essas ponderações, é forçoso concluir que a prioridade concedida à construção de novas escolas de ensino médio, no período em análise, refletiu uma decisão calcada, sobretudo, em critérios

${ }^{23}$ No ano de 2003, as matrículas na rede estadual chegavam a 664.683. Ao final do quadriênio, o total havia se reduzido para 633.625. (Dados obtidos no site do INEP, www.inep.gov.br ).

${ }^{24}$ Ao longo desse período, houve uma queda expressiva nas matrículas estaduais do ensino fundamental devido ao processo de municipalização. Entretanto, esse fenômeno por si só não poderia explicar o aumento da ociosidade, devido ao repasse de parte da rede escolas do nível fundamental para os municípios.

${ }^{25}$ Discutir as possíveis razões dessa queda está além dos objetivos do artigo. Porém, uma hipótese que vem sendo sugerida por demógrafos e especialistas em educação diz respeito à queda das taxas de natalidade, que redunda em um menor crescimento da população em idade escolar. Não se podem esquecer também os índices elevados de evasão escolar no ensino médio.

${ }^{26}$ Dados obtidos no site da Secretaria da Educação, www.sec.ba.gov.br ria estar refletindo uma lógica de maximização eleitoral, tendo em vista a maior visibilidade e o apelo eleitoral dessas ações com respeito às obras de ampliação de escolas e (ou) medidas de reorganização da rede física. As evidências coletadas por esta pesquisa não permitem nem confirmar nem rejeitar essa hipótese, no entanto. O que se pode dizer é que a influência da competição eleitoral, nos dois quadriênios analisados, se fez sentir de forma semelhante no que concerne à sincronia entre o calendário de obras e inaugurações e o calendário eleitoral.

As análises sobre o ciclo político-econômico (political business cycle) pressupõem que governos maximizadores de votos devem ampliar os gastos no período imediatamente anterior às eleições, assim gerando um efeito positivo sobre a renda dos eleitores. Esses modelos também presumem que, no período pós-eleições, a política fiscal deve se tornar mais restritiva, para compensar a expansão anterior, resultando em um movimento cíclico de expansão e contração de gastos (Ames, 1987; Mueller, 1989; Borsani, 2003). No caso brasileiro, é fato corriqueiro a aceleração das obras governamentais no terceiro e quarto anos de mandato, quando os chefes do Executivo buscam fazer o seu sucessor ou viabilizar a reeleição.

O Gráfico 1 mostra a evolução dos gastos de capital da Secretaria da Educação destinados ao ensino básico ao longo do período 1999-2006. ${ }^{28}$ Nos dois quadriênios - 1999/2002 e 2003/2006 é possível identificar um padrão semelhante: os

\footnotetext{
${ }^{27}$ De fato, os estudos realizados pelo Banco Mundial e citados no relatório de 2007 (World Bank, 2007) apontavam a reorganização e ampliação da rede já existente como a melhor estratégia para garantir a expansão do ensino médio no estado.

${ }^{28}$ Para cálculo dos totais ano a ano, subtraiu-se do total das despesas de capital os investimentos realizados no
} ensino superior através das universidades estaduais. 
gastos são de menor monta no primeiro e segundo anos de mandato, crescendo significativamente à medida que se aproxima o período eleitoral (biênios 2001-2002 e 2005-2006). Ou seja, os dados demonstram haver uma sincronização sistemática entre o calendário de obras e inaugurações e o processo político-eleitoral.

Gráfico 1 - Bahia: Evolução da despesa de capital da Secretaria da Educação (exclusive ensino superior), 1999-2006 (R\$ mil)

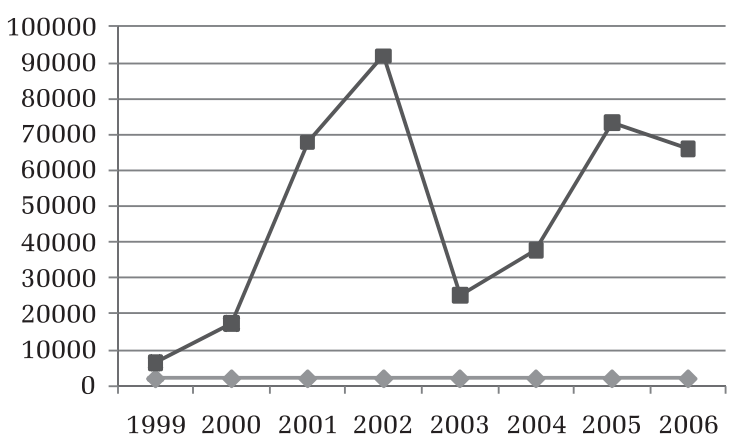

Fontes: Balanços Gerais do Estado, Relatórios de obras (SUCAB)

Em que pese a existência de um padrão comum aos dois períodos estudados, a análise estatística multivariada demonstrou que, durante a gestão das secretárias Renata Prosérpio e Anaci Paim, a alocação de recursos entre os municípios não foi influenciada significativamente por fatores políticopartidários, uma vez que critérios redistributivos foram determinantes na decisão de alocação dos investimentos. Seguindo o mesmo procedimento adotado na seção anterior, utilizou-se um modelo de regressão logística para estimação do impacto de indicadores político-partidários e sociodemográficos sobre a distribuição espacial dos investimentos no período 2003-2006. Incluíram-se as mesmas variáveis independentes do modelo estimado para o período 1999-2002, com algumas pequenas modificações. Em lugar da variável escolas_em, que indicava o tamanho da rede de ensino médio do município, incluiu-se uma variável dummy indicando os municípios que não possuíam nenhuma escola estadual de ensino médio no ano de 2002 (sem_escola). A inclusão desse indicador tinha por objetivo levar em conta as novas diretrizes da Se- cretaria da Educação no sentido de reduzir as desigualdades no acesso ao ensino médio. Os demais indicadores sociodemográficos (força de trabalho na indústria, população, escolarização fundamental) e político-partidários (dummies dos prefeitos) foram mantidos, com exceção da variável vt_secretário. Também seguindo o mesmo procedimento do modelo anterior, os dados para o gasto total foram empilhados por biênio e recodificados como uma variável dependente binária.

\begin{tabular}{|c|c|c|c|c|c|}
\hline Variáveis & B & Erro & Wald & Sig. & $\operatorname{Exp}(B)$ \\
\hline população & $1,759 * *$ & 0,307 & 32,896 & 0,000 & 5,809 \\
\hline trab_indústria & 0,429 & 0,231 & 3,45 & 0,063 & 1,536 \\
\hline esc_fundam. & 0,015 & 0,018 & 0,685 & 0,408 & 1,015 \\
\hline sem escolas & 0,564 ** & 0,202 & 7,768 & 0,005 & 1,758 \\
\hline mun_pobres & $-0,042$ & 0,174 & 0,059 & 0,808 & 0,959 \\
\hline PFL & $-0,05$ & 0,172 & 0,085 & 0,771 & 0,951 \\
\hline pref_coligação & $-0,294$ & 0,181 & 2,640 & 0,104 & 0,745 \\
\hline Constante & $-9,425$ & 2,246 & 17,610 & 0,000 & 0,000 \\
\hline
\end{tabular}

Como seria de se esperar, o indicador do porte populacional do município aparece positivamente relacionado à alocação de investimentos. Por sua vez, o coeficiente estimado para a variável sem_escola indica que, no período, houve uma maior preocupação no sentido de atender a municípios onde a rede estadual de ensino médio ainda não se fazia presente. Nenhuma das demais variáveis apresenta coeficientes significativos. É digno de nota o fato de as variáveis dummy para os prefeitos governistas apresentarem coeficientes negativos, ainda que não significativos.

O modelo parece sugerir que os fatores político-partidários não afetaram a escolha dos municípios que deveriam receber investimentos da Secretaria da Educação no período, contrastando com a análise realizada para o quadriênio 19992002, quando o impacto desses mesmos fatores mostrou-se bastante forte e significativo na regressão logística. Uma possível explicação para essa discrepância entre os dois quadriênios poderia estar no fato de a Secretaria ter estabelecido como meta 
a universalização do acesso ao ensino médio nos municípios durante a gestão Anaci Paim. Uma vez que todos ou quase todos os municípios que não possuíam escolas desse nível de ensino tiveram de ser atendidos para garantir a universalização, teria havido menor espaço para a discriminação entre municípios com base em critérios políticopartidários.

Outro fator que poderia explicar uma menor disposição da Secretaria da Educação em favorecer de forma mais explícita as prefeituras governistas poderia estar nas diferenças relativas ao perfil e trajetória dos dirigentes do órgão nos dois quadriênios. Ao longo da gestão Anaci Paim (e da sua antecessora), uma parte significativa dos cargos-chave da Secretaria da Educação foi ocupada por funcionários de carreira do órgão. Ao menos em tese, essa estratégia de nomeação deve ter garantido um maior insulamento da burocracia setorial, marcando uma diferença importante com respeito ao quadriênio anterior, quando a secretaria foi chefiada pelo então deputado federal Eraldo Tinoco.

É preciso ressaltar, porém, que o modelo permite apenas distinguir entre os municípios que receberam e os que não foram agraciados com recursos, nada dizendo sobre possíveis diferenças no nível de gasto entre os municípios. Ainda assim, a estimação de um modelo de regressão linear simples, utilizando o nível de gasto per capita como variável dependente, não acusou efeitos significativos para a filiação partidária das prefeituras.

Concluindo, pode-se dizer que o programa de expansão da rede física de escolas estaduais assumiu caráter mais fortemente redistributivo ao longo da gestão Anaci Paim, com a construção de novas escolas nos municípios de menor desenvolvimento educacional. Essa reorientação não significou, necessariamente, um aumento da eficiência das ações da Secretaria da Educação. As evidências de que dispomos sugerem, ao contrário, que as decisões relativas à construção ou ampliação de escolas não foram pautadas por critérios mais estritos de atendimento da demanda por escolarização nos municípios, resultando em aumento da ociosidade da rede. Ainda que a priori- dade concedida à construção de novas escolas de ensino médio seja questionável do ponto de vista dos seus resultados, os dados não permitem concluir que as decisões alocativas da Secretaria da Educação seriam consequência de influências político-partidárias, como sugerido por informantes em entrevistas ao autor. O que não quer dizer que a burocracia setorial tenha permanecido, ao longo do período, imune às pressões do jogo políticoeleitoral. De fato, a sincronização entre os ciclos de alta e baixa dos investimentos da secretaria e o ciclo eleitoral, nos dois quadriênios estudados, sugere o contrário.

\section{CONCLUSÃO}

As evidências apresentadas neste artigo demonstram o importante papel desempenhado pelas nomeações de cargos burocráticos tanto no processo decisório de políticas públicas, quanto na conexão entre política eleitoral e políticas públicas no nível estadual. Como notado por Ben Schneider (1994), a política de nomeações tem importância fundamental para o processo de produção de políticas públicas no sistema político brasileiro, em virtude da centralidade do Poder Executivo e da baixa institucionalização da burocracia. No Brasil, assim como em outros países da América Latina, não foi possível institucionalizar plenamente um serviço público profissional e regido por normas "weberianas" de contratação e promoção de pessoal. A administração pública brasileira se caracteriza por uma alta profundidade de nomeações isto é, número significativo de níveis hierárquicos sujeitos às nomeações político-partidárias - e baixa institucionalização das carreiras burocráticas.

Os resultados empíricos do trabalho evidenciam, nesse sentido, a persistência de velhas estratégias de instrumentalização político-eleitoral das políticas sociais, não obstante os avanços obtidos desde a Constituição de 1988. A continuada submissão de políticas sociais em áreas como educação pública à lógica do cálculo político-eleitoral de curto prazo se deve, entre outras razões, ao fato de as 
burocracias setoriais serem institucionalmente frágeis e sujeitas a um grande número de nomeações políticas. Por outro lado, as evidências da pesquisa demonstraram que mesmo em setores marcados por um longo histórico de "partidarização" das decisões, como é o caso da educação pública, coexistem lógicas decisórias técnicas e políticas. Esse achado empírico evidencia a atualidade das hipóteses de Edson Nunes (1997) sobre a combinação sincrética entre diversas "gramáticas políticas", como o clientelismo, o universalismo e o insulamento burocrático, da administração pública brasileira.

A construção de uma estrutura administrativa paralela à burocracia do setor educação, com o intuito de garantir a implementação dos projetos financiados pelo Banco Mundial, também mostra a recorrência de estratégias de reforma que nada têm de novas ou atuais. Autores como Evans (1995) e Geddes (1994) argumentaram persuasivamente que, no caso brasileiro, diante da ineficiência e baixo grau de profissionalização da burocracia pública, a criação de organizações paralelas mais flexíveis, com salários diferenciados e maior grau de insulamento, tornou-se elemento importante na construção do Estado Desenvolvimentista no Brasil pós-1930 (sendo o exemplo paradigmático o Grupo Executivo da Indústria Automobilística criado por Juscelino Kubistcheck nos anos 1950). No caso em análise, o objetivo dos setores reformistas apoiados pelo Banco Mundial era contornar os entraves colocados por uma estrutura burocrática politizada, com funcionários desmotivados e sem as qualificações necessárias à realização do projeto de reforma educacional (Xavier e Verhine, 2004). No entanto, longe de garantir a consecução estrita das metas de reforma, esse paralelismo organizacional apenas serviu para tornar mais evidente a divisão dos espaços ocupados por técnicos e políticos na Secretaria.

O estudo da burocracia estadual do setor educação revelou ainda a persistência do padrão de formulação "não-institucionalizada" de políticas governamentais, identificado por Schneider (1994), uma vez que a formação de coalizões intraburocráticas informais é crucial para garantir a viabilidade técnica e política das ações governamentais. A formação de equipes de perfil mais técnico e com autonomia para colocar em prática ações capazes de romper com as influências político-partidárias na distribuição de cargos e recursos irá depender, quase sempre, da conjuntura política e da disposição do núcleo do governo de enfrentar interesses encastelados na administração pública e nos partidos. Essas dificuldades parecem ser maiores nos níveis subnacionais, onde a politização da burocracia tende a ser maior do que na esfera federal. Em tal cenário, torna-se mais difícil garantir a sustentabilidade política das reformas de política pública, uma vez que a implantação das ações planejadas se torna dependente da estruturação de arranjos decisórios informais, os quais resultam, não raro, de um frágil equilíbrio entre lógicas de cunho burocrático-universalista e político-partidário.

(Recebido para publicação em março de 2009) (Aceito em março de 2010)

\section{REFERÊNCIAS}

ABRUCIO, F. L. Os Barões da Federação: os governadores e a redemocratização brasileira. São Paulo: Hucitec, 1998.

AMES, B. The deadlock of democracy in Brazil. Michigan: The University of Michigan Press: Ann Harbor, 2001.

. Political survival: politicians and public policy in Latin America. Berkeley; London: University of California Press, 1987.

The reverse coattails effect: local party organization in the 1989 Brazilian Presidential Election. American Political Scicence Review, n. 88, 1, 1994, p. 95-111.

AMORIM NETO, O. O poder executivo, centro de gravidade do sistema político brasileiro. In: L Avelar, AO Cintra, eds. O sistema político brasileiro. São Paulo: Editora Unesp; Fundação Konrad-Adenauer, 2007.

ARRETCHE, M. The veto power of sub-national governments in Brazil: political institutions and parliamentary behaviour in the post-1988 period. Brazilian Political Science Review. v. 1, n. 2, p. 40-73, 2007.

BAHIA. Secretaria da Educação e Cultura. Perfil da Educação na Bahia - 2006. Salvador, 2006.

Secretaria da Educação e Cultura. Relatório de Atividades, Exercício 2002. Salvador, 2003a.

. Secretaria da Educação e Cultura. Plano Estratégico da SEC. Salvador, 2003b.

Secretaria da Educação e Cultura. Relatório de Atividades, 1999-2001. Salvador, 2002. 
. Governo do Estado. Plano Plurianual, 19992003 - Bahia de Todos os Tempos. Salvador, Ba, 1999.

BAHIA. Secretaria de Educação do Estado. Relatório de gestão 1995-1998. Salvador, Ba, 1998.

BARROS, R. P.; MENDONÇA, R. Impacto de três inovações institucionais na educação brasileira. Brasília, DF Texto para Discussão - IPEA 1998.

BAUMGARTNER, F. R.; JONES, B. D. Agendas and instability in American politics. Chicago; London: University of Chicago Press, 1993.

BORGES, A. State government, political competition and school decentralisation: comparative lessons from Brazil. Bulletin of Latin American Research. n. 27, 2008, p. 235-254

BORSANI, Hugo. Eleições e economia. Belo Horizonte: Editora UFMG, 2003.

CALVO, E.; MURILLO, M. V. Who delivers? partisan clients in the Argentine Electoral Market. American Journal of Political Science. n. 48, 4, 2004, p. 742-757.

CASTRO, J. A. et al. A reestruturação das políticas federais para o ensino fundamental: descentralização e novos mecanismos de gestão.Brasília, DF: Texto para Discussão, IPEA 2000.

COX, G.; MCCUBBINS, M. Electoral politics as a redistributive game. Journal of Politics. n. 48, 1986, p. 370-389.

CURY, C. R. A educação básica no Brasil. Educação e Sociedade. v. 23, n. 80, 2002, p. 168-200.

DAHLBERG, M.; JOHANSSON, E. On the vote-purchasing behaviour of incumbent governments. American Political Scicence Review. n. 96, 1, 2002, p. 27-40.

EVANS, P. B. Embedded autonomy: states and industrial transformation. Princeton: Princeton University Press, 1995

FIGUEIREDO, A.; LIMONGI, F. Executivo e legislativo na nova ordem constitucional. Rio de Janeiro: Editoral FGV, 1999.

FIGUEIREDO, A. C.; LIMONGI, F. Incentivos eleitorais, partidos e política orçamentária. Dados. v. 45, n. 2, 2002, p. 303-344.

GEDDES, B. Politician's dilemma: building state capacity in Latin America. Berkeley: University of California Press, 1994.

HAGOPIAN, F. Traditional politics and regime change in Brazil. Cambridge: Cambridge University Press, 1996.

HALL, A. Education reform in Brazil under democracy. In: MDAG Kinzo, J Dunkerley (Eds.) Brazil since 1985: politics, economy and society. London: Institute of Latin

LOUREIRO, M.R. ABRUCIO, F. Política e burocracia no presidencialismo brasileiro: o papel do Ministério da Fazenda no primeiro governo Fernando Henrique Cardoso. ๙ Revista Brasileira de Ciências Sociais. v. 14, n. 41, p. 692. 89, 1999 .

MAINWARING, S. Presidentialism in Brazil: the impact of strong constitutional powers, weak partisan powers, and robust federalism. In: S Mainwaring, MS Shugart
(Eds.) Presidentialism and democracy in Latin America. Cambridge: Cambridge University Press, 1997.

Rethinking party systems in the third wave of democratization: the case of Brazil. Stanford, Calif.: Stanford University Press, 1999.

MAYHEW, D. R. Congress: the electoral connection. New Haven: Yale University Press, 1974.

MUELLER, D.C. Public choice II, Rev. edn. Cambridge [England]; New York: Cambridge University Press, 1989.

OLIVIERI, C. Política, burocracia e redes sociais: as nomeações para o alto escalão do Banco Central do Brasil. Revista de Sociologia e Política. n. 29, p. 147-168, 2007.

PAGE, E. Political authority and bureaucratic power: a comparative analysis, 2nd edn. New York: Harvester Wheatsheaf, 1992.

PLANCK, D. N. The means of our salvation: public education in Brazil, 1930-1995. Boulder, Colo.; Oxford: Westview, 1996.

ROCHA, C. A descentralização político-administrativa do ensino público em Minas gerais: um Caso de mudança institucional. Tese de Doutorado. UNICAMP. 2000.

SABATIER, P. A.; JENKINS-SMITH, H. The advocacy coalition framework. In: PA Sabatier, ed. Theories of the policy process. Boulder, Colo.: Westview Press, 1999:viii, 289.

SAMUELS, D. Ambition, federalism, and legislative politics in Brazil. Cambridge: Cambridge University Press, 2003.

The gubernatorial coattails effect: Federalism and congressional elections in Brazil. Journal of Politics. v. 62 , n. 1, 2000, p. 240-253.

SCHNEIDER, B. Burocracia pública e política-industrial no Brasil. São Paulo: Editora Sumaré, 1994

SILBERMAN, B. S. Cages of reason-: the rise of the rational state in France, Japan, the United States, and Great Britain. Chicago: University of Chicago Press, 1993.

SKOCPOL, T. Protecting soldiers and mothers-: the political origins of social policy in the United States. Cambridge, Mass.; London: Belknap Press of Harvard University Press, 1992.

SOUZA, C. Constitutional engineering in Brazil-: the politics of federalism and decentralization. Basingstoke: Macmillan, 1997

XAVIER, A.; VERHINE, R. O Projeto Bahia: um estudo de caso. Relatório de avaliação preparado para o Banco Mundial. Mimeo. Salvador, 2004.

WORLD BANK. Bahia Education Project. The World Bank:- Washington D.C., 2000.

WORLD BANK. Bahia Education Project II. The World Bank: Washington D.C., 2003.

WORLD BANK. Bahia Education Project II Implementation and completion report. The World Bank, Washington D.C., 2007. 


\section{POLITICAL AND ELECTORAL DYNAMICS, STATE BUREAUCRACY AND SOCIAL SPENDING}

\section{André Borges}

This paper analyzes the effects of decentralization of authority and fiscal resources on processes and results of public policies. It seeks to trace the connections between electoral politics, bureaucracy, formulation and implementation of social policies in the sphere of states. It focuses on the political construction and renovation of state schools in Bahia over two terms (1999-2002 and 2003-2006). This paper concentrates on the impact of electoral and party politics over the allocation of investments in the Secretary of Education between the municipalities of the state, and also examines the role of appointments of senior positions in the sectorial bureaucracy in the construction of public policy. The analysis relies on a multimethod strategy, which combines multivariate statistical models and traditional techniques of case studies.

KEYWORDS: State government, elections, social spending, bureaucracy.

\section{LA DYNAMIQUE POLITIQUE ELECTORALE, LA BUREAUCRATIE ET LES DEPENSES SOCIALES AU NIVEAU DES ÉTATS}

\section{André Borges}

Cette étude présente l'analyse des effets de la décentralisation des pouvoirs et des ressources fiscales sur les processus et les résultats des politiques publiques. Elle cherche à établir les liens entre la politique électorale, la bureaucratie, la formulation et la mise en œuvre de politiques sociales qui relèvent des Etats. Les politiques de construction et de rénovation des écoles publiques, mises en œuvre par l'Etat de Bahia pendant deux mandats (1999-2002 et 2003-2006), ont été particulièrement prises en considération. Larticle se concentre sur l'impact de la politique électorale et des partis quant à la distribution des fonds d'investissements entre les municipalités de cetÉtat, répartition faite par le Secrétariat de l'éducation. Il examine aussi le rôle des nominations à des postes de direction pour la construction des politiques publiques. L'analyse repose sur une stratégie multi méthodes qui combine des modèles statistiques variés et des techniques traditionnelles d'études de cas.

Mots-clés: gouvernement d'état, élections, dépenses sociales, bureaucratie.

André Borges - Doutor em Ciência Política pela Universidade de Oxford. Professor do Instituto de Ciência Política da UnB. Nos últimos anos, publicou trabalhos na Revista de Sociologia e Política, Brazilian Political Science Review e Public Administration and Development. Participa regularmente dos GTs Estado e Políticas Públicas da ANPOCS e ABCP. Bolsista de produtividade nível II do CNPq. Atualmente é membro do Observatório das Metrópoles, desenvolvendo projeto de pesquisa sobre geografia do voto e comportamento eleitoral nos estados brasileiros.andrebc@unb.br 
